\title{
Arakawa's Reaction and Cell Content of Human Milk.
}

89th Report of the Petoxidase Reaction.

By

Akira Sato and Tamotsu Suzuki.

(佬藤 彰) (制命 木 保)

(From the Department of Pediatrics, Faculty of Medicine, Tohoku Imperial University, Sendai.

Director: Prof. A. Sato.)

\section{Introduction.}

Since the publication of A rakaw a's ${ }^{1)}$ reaction from this Laboratory, a number of papers have appeared concerning the difference between the Arakawa-positive* and the A rakawa-negative milk. At the time of the publication of Arakawa's reaction we thought that the difference between these two kinds of human milk was that of peroxidase content, and that the other possible difference might be the presence of a poison or poisons in the A rakawa-negative milk.

When $\mathrm{Nozal}^{2} \mathrm{i}^{2}$ started to investigate chlorin content of human milk, it was our expectation that, in spite of the biological difference between those two kinds of human milk, such a chemical constituent as chlorin would remain of the same concentration in both kinds of milk. The result of his investigation was quite different as was described in his paper. Now that a number of papers concerning A rakawa's reaction from this Laboratory have been published, we have come to think that a quantitative difference of chemical constituents

1) T. A rakawa, Tohoku J. Exp. Med., 1930, 16, 118.

* "A rakaw ampositive" may be used in two different senses. One of these is: A rakawa-positive in a bioehemieal sense. A sample of human milk is said to have become Arakawa-positive, when it became bIue on the addition of Arakawa's reagent. Here it means that the sample was not negative to Arakawa's reaction. The other of these two senses is: A ra $\mathrm{kaw}$ a-positive in a clinical sense. A sample of human milk is clinieally A raka wa-positive only when it shows such a reaction as $\#$ or H in one minute of the addition of A rakawa's reagent. Another sample of human milk may be A rak a w a-positive in the first described sense, byt yet clinically negative.

2) J. Nozaki, Tohokn J. Exp. Med., 1934, 23, 60 . 
between the Arakawa-positive and the Arakawa-negative milk is even rather natural.

We have started the present work assuming that a cytological difference will be found between these two kinds of human milk, especially because peroxidase-positive cells of milk interested A. Sato, one of us, long ago. It will here be remarked how $A$. Sato and $K$. Shoj $\mathrm{i}^{3}$ succeeded in evolving a device of the counting chamber method of peroxidase reaction-perhaps the only humid method of blood counting utilizing peroxidase reaction. The following is a short history of the device:-

Since the device of the copper peroxidase reaction by Sato (one of us) and Sekiy ${ }^{4}$ in 1919 , the former and K. Sh oji had been contriving to apply the copper peroxidase reaction (of blood films) to the counting chamber method, so that simultaneously with the total white cell count, myeloic and lymphatic cells might be easily differentiated. They tried and tried, but in vain. At last they tried it on milk and, after several trials, found one blue stained cell in a specimen, which convinced them of a possibility of the counting chamber peroxidase method of blood. And they succeeded at last. It was about two year's after the device of the copper peroxidase reaction on blood films.

\section{Method of Investigation.}

1. Materials. Milk was tested with Arakawa's reagents and the result was noted.

2. Technique of the examination of peroxidase-positive cells. After centrifugalization of a milk sample $(2 \mathrm{ccm}$.) for about fifteen minutes at ca. 3,000 turns per minute, the plasma-the second layer - was tested with Arak aw a's reagents and the result was noted too, and the third layer-the bottom layer-smears were made. These films were stained by Sato-Sekiya's ${ }^{4}$ original copper peroxidase method and peroxidase-positive cells were estimated at the microscopic examination (Cf. Fig.).

\section{Result of Investigation.}

1. Relation between Arakawa's reaction and content of peroxidase-positive cells.

3) A. S a to and K. Sho ji, Journ. of Labor. and Clin. Med., 1928, 13, 1058.

4). A. Sato and S. Sekiya, Tohoku Igaku-Zasshi, 1920, 6, 534; Tohoku J. Exp. Med., 1926, 7, 111. 
A glance at Table 1 will give one the impression that A rakawa's reaction goes hand in hand with cell content. A milk sample of normal Arakawa's reaction is of a high cell centent, while one of weak reaction is a low cell content (Cf. Table 1).

From this impression, we may arbitrarily assume that a milk sample of strong or normal A rakawa's reaction corresponds to the cell content of the sign H+ (Cf. Footnote to Table 1), one of

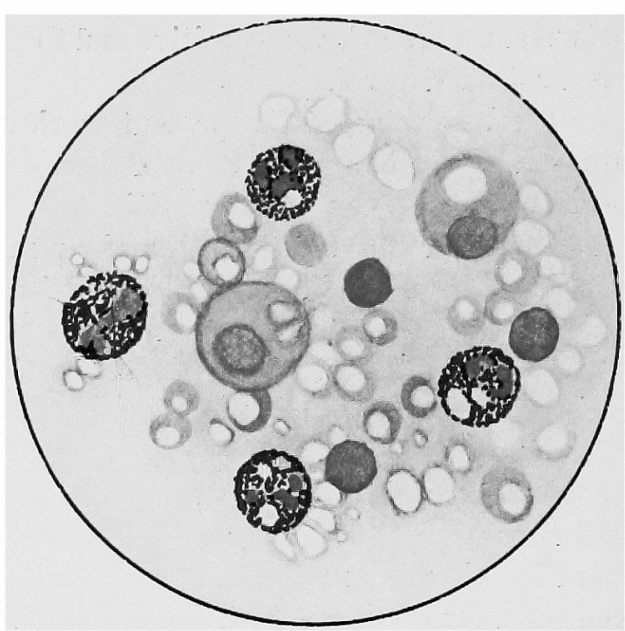

Fig. Smear of centrifuged human milk stained with Sato-Sekiya's copper peroxidasere action (original method). Blue cells are peroxidasepositive.

intermediate reactions to that of the sign $H$ and one of the completely or almost negative reaction to that of the sign + .

Then the milk samples tabulated in Table 1 will be distributed as will be shown in Table 2 (Cf. Table 2 ).

As has been shown in Table 2, 9 milk samples out of the 20 belonging to strong or normal Arakawa's reaction were of the cell content $H^{+}$, and 11 samples of the cell content $H$. But there was no sample of the cell content + . And of 10 samples belonging to the intermediate reaction, 9 samples were of the cell content $H$, and only one of the cell content $\#$. There was no sample of the cell content +. As to the completely or almost completely negative reaction, 20 samples were of the cell content + and 7 of the cell content + . There was none of the cell contten 1 (Cf. Table 2).

From this Table (Cf. Table 2), it will be seen that there is an approximate proportion between the strength of Arakawa's reaction and the cell content. Milk samples of strong Arakawa's reaction are of a high cell content, and ones of negative reaction of a low cell content.

Of all the 58 samples examined, there was an exceptional case. That was milk sample from the left side of Case 27. It was of an intermediate Arakawa's reaction and that a weak reaction. Its cell 
TABLE, 1.

A rakawa's reaction and peroxidase-positive eells of human milk.

\begin{tabular}{|c|c|c|c|c|c|}
\hline \multirow[b]{2}{*}{ No. } & \multirow[b]{2}{*}{ Tame } & \multirow[b]{2}{*}{ Side } & \multicolumn{2}{|c|}{ Arakawa's reaction of mother's milk } & \multirow{2}{*}{$\begin{array}{l}\text { Peroxi- } \\
\text { dase- } \\
\text { posi- } \\
\text { tive } \\
\text { cells }\end{array}$} \\
\hline & & & $\begin{array}{c}\text { Whole milk } \\
\left(0^{\prime}\right)\left(1^{\prime}\right)\left(\mathbf{2}^{\prime}\right)\left(3^{\prime}\right)\left(4^{\prime}\right)\left(5^{\prime}\right)\end{array}$ & $\begin{array}{c}\text { Milk plasma } \\
\left(0^{\prime}\right)\left(1^{\prime}\right)\left(2^{\prime}\right)\left(3^{\prime}\right)\left(4^{\prime}\right)\left(5^{\prime}\right)\end{array}$ & \\
\hline 1 & hmi & $\begin{array}{l}\text { right } \\
\text { \{right } \\
\text { left } \\
4 \text { days } \\
\text { right } \\
6 \text { day } \\
\text { right } \\
7 \text { day }\end{array}$ & $\begin{array}{l}(-)(-)(-)(-)(-)( \pm) \\
(-)(-)(-)(-)(-)(-) \\
(-)(-)(-)(-)(-)(-) \\
\text { s after daily administratio } \\
\text { I (-) }(-)(-)(-)(-)(-) \\
\text { s after daily administratio } \\
\text { I }(-)(-)(-)( \pm)( \pm)( \pm) \\
\text { s after daily administratio }\end{array}$ & $\begin{array}{l}(-)(-)(-)(-)( \pm)( \pm) \\
(-)(-)(-)(-)(-)(-) \\
(-)(-)(-)(-)( \pm)( \pm) \\
\text { of vitamin } \mathrm{B} \\
(-)(-)(-)(-)(-)( \pm) \\
\text { a of vitamin } \mathrm{B} \\
(-)(-)( \pm)(+)(+)(+) \\
\text { a of vitamin } \mathrm{B}\end{array}$ & $\begin{array}{l}(+) \\
(+) \\
(+) \\
(+) \\
(+)\end{array}$ \\
\hline $\begin{array}{l}2 \\
3 \\
4\end{array}$ & $\begin{array}{l}\text { Daikoku } \\
\text { Hanasaka } \\
\text { Ohto }\end{array}$ & $\begin{array}{l}\text { left } \\
\text { left } \\
\text { right } \\
\text { right } \\
2 \text { day } \\
\text { right } \\
3 \text { das } \\
\text { right } \\
5 \text { days } \\
\text { right } \\
7 \text { dag } \\
\text { right } \\
16 \mathrm{da}\end{array}$ & 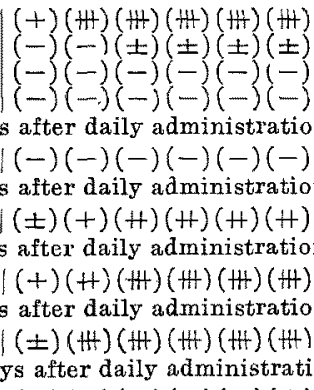 & 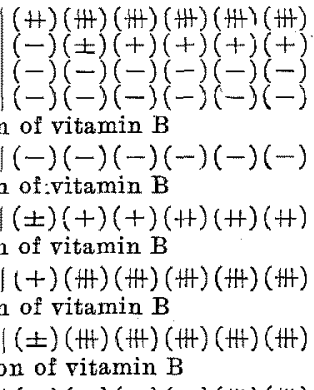 & $\begin{array}{l}(\text { HII) } \\
(+) \\
(+) \\
(+) \\
(H) \\
(H) \\
(H) \\
(H)\end{array}$ \\
\hline 5 & Chiba & & $(+)(H)(H)(H)(H)(H)$ & $( \pm)(+)(+)(+)(H)(H)$ & $($ (H) \\
\hline 6 & Koh- & $\left\{\begin{array}{l}\text { might } \\
\text { left }\end{array}\right.$ & $( \pm)(+)(+)(+)(+)(+4)$ & $(-)( \pm)(+)(+1)(+4)(H)$ & $(+4)$ \\
\hline $\begin{array}{l}7 \\
8\end{array}$ & & $\begin{array}{l}\text { left } \\
\text { left } \\
\text { left }\end{array}$ & $\begin{array}{l}(-)(+)(+)(H)(H)(H)(H)(H)(H)(H)(H)(H)(H)(H)(H)(H)(H)(H)(H) \\
( \pm)(H)(H)(H)\end{array}$ & $\begin{array}{l}(-)( \pm)(+)(+)(H)(H)(H)(H)(H)(H)(H) \\
( \pm)(H)(H)(H)(H)(H)(H)(H) \\
(+)(H)(H)\end{array}$ & $\begin{array}{l}(+H) \\
(H+) \\
(H+)\end{array}$ \\
\hline & & $\begin{array}{l}\text { on th } \\
\text { left } \\
2 \text { day }\end{array}$ & $(H)(+H)(H)(H)(H$ & $( \pm)(H)(H)(H)(H)(H)$ & $(H)$ \\
\hline 9 & Furusawa & $\left\{\begin{array}{l}\text { right } \\
\text { left } \\
\text { left } \\
3 \text { day }\end{array}\right.$ & \begin{tabular}{|}
$\mid( \pm)(H)(H)(+H)(H)(H)$ \\
$(-)( \pm)( \pm)(+)(+)(+)$ \\
$(-)(-)( \pm)( \pm)( \pm)(+)$
\end{tabular} & $\begin{array}{l}( \pm)(H)(H)(H)(H)(H) \\
(-)(+)(+)(+)(H)(H) \\
( \pm)(+)(H)(H)(H)(H)\end{array}$ & $\begin{array}{l}(+4) \\
(+H) \\
(H)\end{array}$ \\
\hline 10 & Tsuji & $\left\{\begin{array}{l}\text { left } \\
\text { right } \\
\text { left } \\
13 \mathrm{da}\end{array}\right.$ & 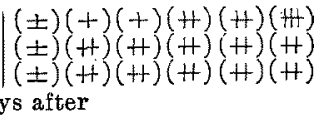 & $\mid \begin{array}{l}( \pm)(H)(H)(H)(H)(H)(H)(H)(H)(H) \\
( \pm)(H)(H)(H)(H)(H)(H)(H)\end{array}$ & $\begin{array}{l}(\text { (H) } \\
(\text { H) } \\
\text { (H) }\end{array}$ \\
\hline 11 & & & $\mid \begin{array}{l}(-)(+)(+)(++)(+H)(H) \\
(-)(+)(+)(+)(++)(H)\end{array}$ & $(-)( \pm)( \pm)(+)(+)(+)$ & $(+)$ \\
\hline 12 & & & $(-)(-)(-)(-)(-)( \pm)(-)(-)(-),( \pm)$ & 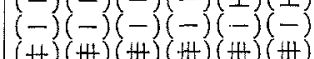 & $(+4)$ \\
\hline 13 & & & $\mid \begin{array}{l}( \pm)(+)(H) \\
( \pm)(+H)(\#)(H)(H)(H)\end{array}$ & $(H)(H)(H)(H)(H)(H)$ & $(+4)$ \\
\hline 14 & Sho & & $(-)(-)( \pm)( \pm)(+)(+)$ & $(-)(-)(-)(-)( \pm)( \pm)$ & +1 \\
\hline 15 & Suzuki & & $(-)(+)(+)(+)(H)(H$ & $(-)(-)( \pm)(+)(+)(+)$ & $(+)$ \\
\hline
\end{tabular}




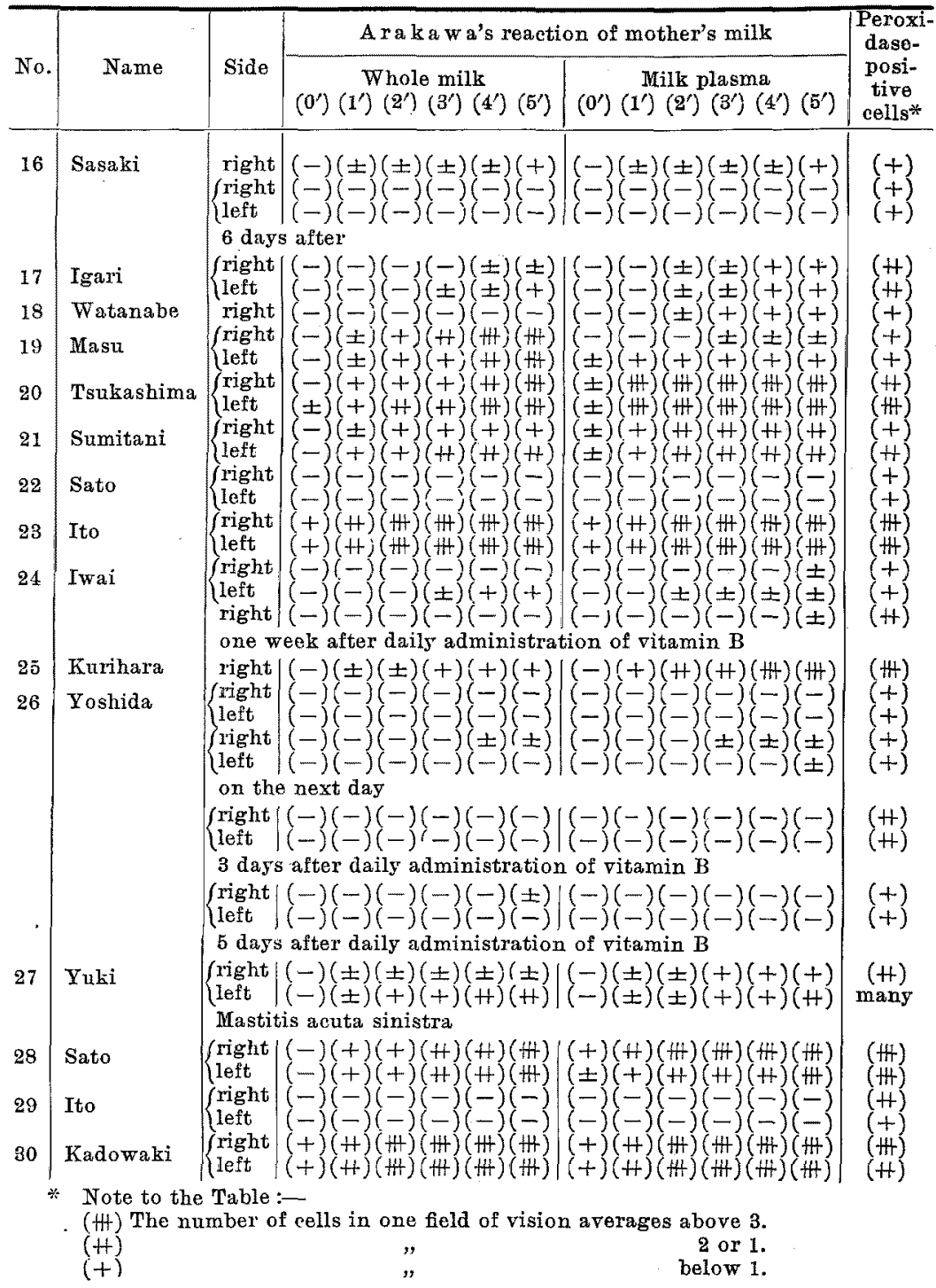

content was very high, so that one field of vision presented many peroxidase-positive cells. The mother had mastitis acuta on her left breast.

2. Effect of vitamin $\mathrm{B}^{* *}$ on cell content.

* Vitamin $B_{1}$ is meant throughout the paper. 
Table 2.

Relation between Arak awa's reaction and cell eontent.

\begin{tabular}{|c|c|c|c|c|}
\hline \multicolumn{2}{|c|}{ Arakawa's reaction } & $\begin{array}{l}\text { Strong or } \\
\text { normal }\end{array}$ & Intermediate & $\begin{array}{l}\text { Completely or } \\
\text { almost com- } \\
\text { pletely negative }\end{array}$ \\
\hline \multicolumn{2}{|c|}{ Total number of samples } & 20 samples & 10 samples & 27 samples \\
\hline \multirow{4}{*}{$\begin{array}{l}\text { Approximate } \\
\text { content of } \\
\text { peroxidase- } \\
\text { positive cells" }\end{array}$} & . $H$ & $\begin{array}{l}9 \text { samples } \\
(45 \%)\end{array}$ & $\begin{array}{l}\text { I sample } \\
(10 \%)\end{array}$ & 0 \\
\hline & $H$ & 11 samples & $\begin{array}{l}9 \text { samples } \\
(90 \%)\end{array}$ & $\begin{array}{c}7 \text { samples } \\
(26 \%)\end{array}$ \\
\hline & + & 0 & 0 & $\begin{array}{c}20 \text { samples } \\
(74 \%)\end{array}$ \\
\hline & Average & H & H & + \\
\hline
\end{tabular}

* Cf. Foot-note to Table 1.

Table 3 shows a collection of only a few cases of lactating women treated with vitamin $B$.

Table 3.

Effect of vitamin $B$ on content of peroxidase-positive cells.

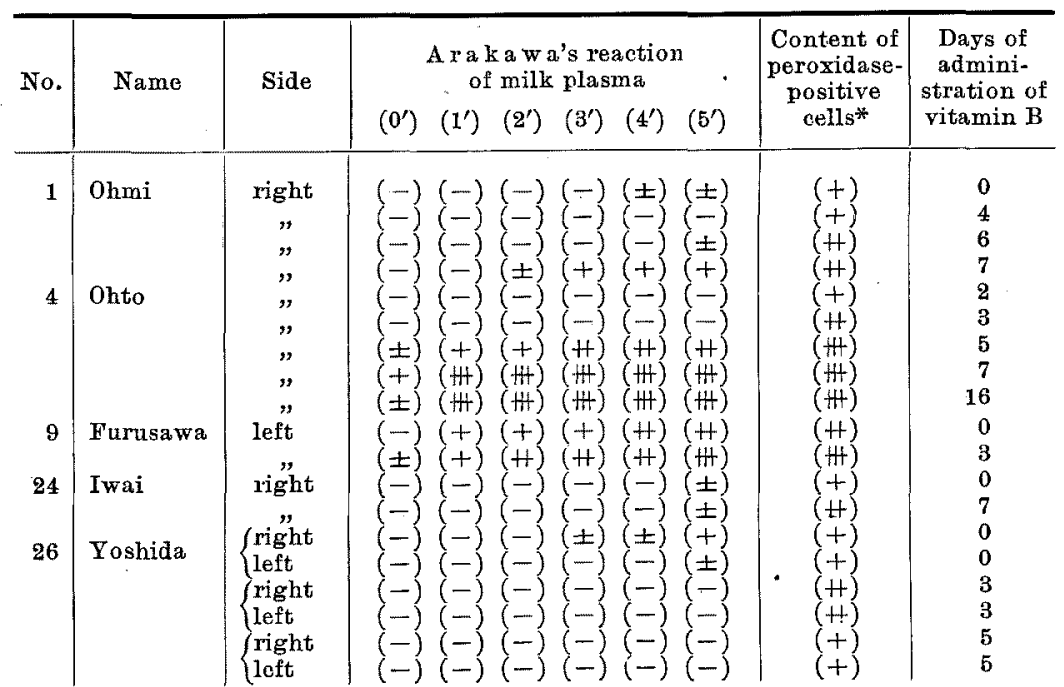

* Cf. Foot-note to Table 1. 
As has been shown in a number ${ }^{5-10)}$ of papers published from this Laboratory, A rakawa's reaction will become stronger on an administration of vitamin B to a lactating woman, or at least A rakawanegative milk will, if a lactating woman has been treated with vitamin $\mathrm{B}$, become less poisonous ${ }^{11)}$ even allowing that the reaction should remain negative all the same.

A certain effect of vitamin $B$ will also be seen from the change of cell content of milk. When a lactating women with negative or weak A rakawa's reaction has been treated with vitamin $B$ for some time, the cell content will become large, notwithstanding that the reaction has not improved much (Cf. Table 3).

3. A rakawa's reaction of milk plasma.

54 samples (75\%) showed no difference of A raka wa's reaction between whole milk and milk plasma, and in 10 samples (14\%) milk plasma became more intensively positive to Arakawa's reaction than the whole milk, but there were 8 samples $(11 \%)$ that showed a weakening of the reaction of milk plasma. But in those samples that showed a stronger reaction or a weakening of the reaction, the grade of the change was not remarkable in most cases, so that in practice it may be said that Arakawa's reaction of whole milk generally represents that of milk plasma.

\section{Remarks.}

As to the significance of the cell-rich and the cell-poor milk, it will be related in the next paper on the same problem ${ }^{12}$.

\section{Conclusion.}

Human milk positive to Arakawa's reaction is of a higher content in peroxidase-positive cells than A rakawa-negative is.

5) A. Sato, Nippon no Ikai, 1930, 20, 11; Jikken Iho, 1931, 17, 323; 1932, 18, 1292 ; $1933,19,1554$.

6) M. Chib a, Tohoku J. Exp. Med., 1932. 19, 486.

7) T. Suzuki, Ibid., 1984, 23, 23.

8) X. Ug a, Ibid., 1985, 25, 169.

9) T. Suzuki, Ibid., 1935, 25, 186.

10) J. K i u ra, Ibid., 1935, 27, 360 and 374.

11) A. Taka mats u, Ibid. 1934, 23, 46.

12) Cf. T. S u z ki, the 9lst Report of Peroxidase Reaction, to be published in this Journal. 